\title{
Kinetic study of hydromagnesite thermolysis by constant rate thermal analysis
}

Jaouher Diouani and Kais Nahdi ${ }^{*}$

Laboratoire d'Application de la Chimie aux Ressources et Substances Naturelles et à l'Environnement (LACReSNE), Université de Carthage, Faculté des Sciences de Bizerte, 7021 Zarzouna, Bizerte, Tunisia

\section{ABSTRACT}

k_nahdi@yahoo.fr

The present work is focused on the kinetic study of hydromagnesite thermal decomposition carried out by constant rate thermal analysis technique at $5 \mathrm{hPa}$ partial pressure. The apparent activation energies were measured experimentally all along the decomposition without any assumption about the rate law of the determining step. Under these conditions the decomposition of hydromagnesite occurs in two steps. The first step is a dehydration which occurs with apparent activation energy of $60 \mathrm{~kJ}^{-1} \mathrm{~mol}^{-1}$ and D4 kinetic model. The second step is essentially decarbonatation, which occurs according to an F1 kinetic model and activation energy equal to $95 \mathrm{~kJ}^{\mathrm{mol}}{ }^{-1}$.

\section{Indexing terms/Keywords}

activation energy, hydromagnesite, constant rate thermal analysis, kinetic.

\section{Academic Discipline And Sub-Disciplines}

Chemistry

\section{SUBJECT CLASSIFICATION}

Chemistry subject classification

\section{TYPE (METHOD/APPROACH)}

Experimental study

\section{Council for Innovative Research}

Peer Review Research Publishing System

\section{Journal: Journal of Advances in Chemistry}

Vol. 11, No. 9

www.cirjac.com

editorjaconline@gmail.com, editor@cirjac.com 


\section{INTRODUCTION}

Basic magnesium carbonates with general formula $x \mathrm{MgCO}_{3} \cdot \mathrm{Mg}(\mathrm{OH})_{2} \cdot \mathrm{yH}_{2} \mathrm{O}$ [1] are considered the most important compounds of the magnesium industry. Two chemical formulae were proposed for hydromagnesite: $\mathrm{Mg}_{5}\left(\mathrm{CO}_{3}\right)_{4}(\mathrm{OH})_{2} \cdot 4 \mathrm{H}_{2} \mathrm{O}[2]$ and $\mathrm{Mg}_{4}\left(\mathrm{CO}_{3}\right)_{3}(\mathrm{OH})_{2} \cdot 3 \mathrm{H}_{2} \mathrm{O}$ [3].

Hydromagnesite with chemical formula $\mathrm{Mg}_{5}\left(\mathrm{CO}_{3}\right)_{4}(\mathrm{OH})_{2} \cdot 4 \mathrm{H}_{2} \mathrm{O}$ is the most commonly available magnesium hydroxyl carbonate. It has been widely used in various industries such as toothpaste, painting, cosmetic manufacturing, plastic and rubber. It is also used as precursor for the synthesis of other magnesium-based materials [4-7] and as fire retardant agent $[5,8]$.

Thanks to the fundamental interest and industrial importance in the production of magnesium oxide MgO, several works have been subjected to the thermoanalytical studies of hydromagnesite thermal decomposition for revealing the reaction path way and kinetic mechanism [5,9-24].

Hydromagnesite has been shown [9-14] to decompose endothermically releasing water and carbon dioxide over a temperature range of approximately $220-550^{\circ} \mathrm{C}$ :

$\mathrm{Mg}_{5}\left(\mathrm{CO}_{3}\right)_{4}(\mathrm{OH})_{2} \cdot 4 \mathrm{H}_{2} \mathrm{O}(\mathrm{sd})=5 \mathrm{MgO}(\mathrm{sd})+4 \mathrm{CO}_{2}(\mathrm{~g})+5 \mathrm{H}_{2} \mathrm{O}(\mathrm{g})$

Many of these studies focused on the abrupt exothermic peak observed during the thermal decomposition process [9$14,17]$.

Three reaction pathways were proposed for the thermal decomposition of hydromagnesite. Some authors [14,16,18,21] have proposed a decomposition in two steps as following:

Step 1: $\mathrm{Mg}_{5}\left(\mathrm{CO}_{3}\right)_{4}(\mathrm{OH})_{2} \cdot 4 \mathrm{H}_{2} \mathrm{O}(\mathrm{sd}) \rightarrow \mathrm{Mg}_{5}\left(\mathrm{CO}_{3}\right)_{4}(\mathrm{OH})_{2}(\mathrm{sd})+4 \mathrm{H}_{2} \mathrm{O}(\mathrm{g})$

Step 2: $\quad \mathrm{Mg}_{5}\left(\mathrm{CO}_{3}\right)_{4}(\mathrm{OH})_{2}(\mathrm{sd}) \rightarrow 5 \mathrm{MgO}(\mathrm{sd})+\mathrm{H}_{2} \mathrm{O}(\mathrm{g})+4 \mathrm{CO}_{2}(\mathrm{~g})$

Other authors $[5,9-13,15,18,22-24]$ have proposed a mechanism of three-step reaction as following:

Step 1: $\mathrm{Mg}_{5}\left(\mathrm{CO}_{3}\right)_{4}(\mathrm{OH})_{2 .} 4 \mathrm{H}_{2} \mathrm{O} \quad(\mathrm{sd}) \rightarrow \mathrm{Mg}_{5}\left(\mathrm{CO}_{3}\right)_{4}(\mathrm{OH})_{2}(\mathrm{sd})+4 \mathrm{H}_{2} \mathrm{O}(\mathrm{g})$

Step2: $\mathrm{Mg}_{5}\left(\mathrm{CO}_{3}\right)_{4}(\mathrm{OH})_{2}(\mathrm{sd}) \rightarrow \mathrm{Mg}_{4}\left(\mathrm{CO}_{3}\right)_{4}(\mathrm{sd})+\mathrm{MgO}(\mathrm{sd})+\mathrm{H}_{2} \mathrm{O}(\mathrm{g})$

Step $3: \mathrm{Mg}_{4}\left(\mathrm{CO}_{3}\right)_{4}(\mathrm{sd}) \rightarrow 4 \mathrm{MgO}(\mathrm{sd})+4 \mathrm{CO}_{2}(\mathrm{~g})$

When thermal decomposition of hydromagnesite was carried out in CRTA conditions [19] five steps have been proposed to describe the corresponding mechanism:

Step 1: $\mathrm{Mg}_{5}\left(\mathrm{CO}_{3}\right)_{4}(\mathrm{OH})_{2} \cdot 4 \mathrm{H}_{2} \mathrm{O}(\mathrm{sd}) \rightarrow \mathrm{Mg}_{5}\left(\mathrm{CO}_{3}\right)_{4}(\mathrm{OH})_{2} \cdot 2 \mathrm{H}_{2} \mathrm{O}(\mathrm{sd})+2 \mathrm{H}_{2} \mathrm{O}(\mathrm{g})$

Step 2: $\mathrm{Mg}_{5}\left(\mathrm{CO}_{3}\right)_{4}(\mathrm{OH})_{2} .2 \mathrm{H}_{2} \mathrm{O}(\mathrm{sd}) \rightarrow \mathrm{Mg}_{5}\left(\mathrm{CO}_{3}\right)_{4}(\mathrm{OH})_{2}(\mathrm{sd})+2 \mathrm{H}_{2} \mathrm{O}(\mathrm{g})$

Step 3: $\mathrm{Mg}_{5}\left(\mathrm{CO}_{3}\right)_{4}(\mathrm{OH})_{2}(\mathrm{sd}) \rightarrow \mathrm{Mg}_{4}\left(\mathrm{CO}_{3}\right)_{4}(\mathrm{sd})+\mathrm{MgO}(\mathrm{sd})+\mathrm{H}_{2} \mathrm{O}(\mathrm{g})$

Step4: $\mathrm{Mg}_{4}\left(\mathrm{CO}_{3}\right)_{4}(\mathrm{sd}) \rightarrow 4 \mathrm{MgO}(\mathrm{sd})+4 \mathrm{CO}_{2}(\mathrm{~g})$

Step 5: $4 \mathrm{MgO}(\mathrm{sd}) \rightarrow 4 \mathrm{Mg}(\mathrm{sd})+2 \mathrm{O}_{2}(\mathrm{~g})$

It was shown that the mechanism pathway depends strongly on the experimental conditions such as sample preparation method, particle shape, heating rate and grain size.

Concerning the kinetic study of thermal decomposition of hydromagnesite, only few works exist $[18,21,23,24]$ (Table 1).

Table 1. Literature data on the kinetics parameters of hydromagnesite thermal decomposition

\begin{tabular}{|c|c|c|c|c|}
\hline Authors & Atmosphere & Decomposition step & Kinetic law & $\mathrm{Ea} / \mathrm{kJ} \mathrm{mol}^{-1}$ \\
\hline N.Koga and col. [18] & N2 & $\begin{array}{l}\text { dehydration } \\
\text { dehydroxylation } \\
\text { decarbonation }\end{array}$ & $\begin{array}{l}\text { D3 } \\
\text { D3 } \\
\text { F1 }\end{array}$ & $\begin{array}{l}89 \\
216 \\
141\end{array}$ \\
\hline LIU XIn-wein and col. [21] & air & $\begin{array}{l}\text { dehyd+dehydrox } \\
\text { decarbonation }\end{array}$ & $\begin{array}{l}\text { D3 } \\
\text { A1.5 }\end{array}$ & $\begin{array}{l}51.84 \\
191.97\end{array}$ \\
\hline D. Bhattacharjya and col. [23] & N2 & decarbonation & - & $\begin{array}{l}174 \\
202\end{array}$ \\
\hline H. Ren and col. [24] & N2 & $\begin{array}{l}\text { dehydration } \\
\text { dehydroxylation } \\
\text { decarbonation }\end{array}$ & $\begin{array}{l}\text { D1 } \\
\text { C1.5 } \\
\text { A1 }\end{array}$ & $\begin{array}{l}18.27 \\
22.41 \\
70.79\end{array}$ \\
\hline
\end{tabular}


As can be seen, the kinetic decomposition of hydromagnesite was studied using only constant heating rate under $\mathrm{N}_{2}$ or air atmosphere. The dehydration steps are described by diffusion mechanism (D1 or D3) but the decarbonatation step is described by nucleation mechanism (F1 or A1). To our knowledge, no work has been done concerning the kinetic study of hydromagnesite thermal decomposition using CRTA technique.

It is widely accepted that conventional thermogravimetry which subjects samples to a linear heating rate can have a major influence on the information content of the TG curve and on the properties of the heat treated products. This can be a source of irreproducibility and highlights the importance that constant transformation rate thermal analysis (CRTA) can have $[25,26]$. CRTA permits a constant reaction rate slow enough to minimise the temperature and pressure gradients within the reacting sample and thus results in a more reproducible experiment [27]. It gives generally better separation of intermediate stages in thermal decomposition. CRTA can also be used for kinetic studies of transformations [28].

Besides, CRTA has been employed with success in the study of the stability and thermal decomposition pathways of minerals such as attapulgite [29], hydromagnesite [19], hydrozincite and smithsonite [30], aurichalcite [31], hydrotalcite [32], hydrated borates [33], kaolinite [34], brucite [35], cerium cyclophosphate [36], neodymium cyclophosphate [37] and modified minerals such as mechanochemically activated and intercalated kaolinites [38,39].

The present work aims to contribute to the kinetic study of the thermal decomposition of hydromagnesite using CRTA technique.

\section{EXPERIMENTAL AND METHODS}

\subsection{Sample preparation}

$3 \mathrm{~g}$ of $\mathrm{MgCl}_{2}$ was dissolved in freshly prepared $33 \mathrm{~mL}$ of aqueous urea solution mixed with $43 \mathrm{~mL}$ of ethylene glycol in a $100 \mathrm{~mL}$ round bottom flask. The $\mathrm{pH}$ of the final reaction mixture was 7.2. The mixture was refluxed at $110 \pm 10^{\circ} \mathrm{C}$ for $12 \mathrm{~h}$ in air under continuous stirring. Afterwards, the mixture was cooled to room temperature and the product was filtered. The solid phase of hydromagnesite was collected and washed several times with deionized water to remove all other soluble materials followed by final washing with alcohol. The washed product was dried at $110-120^{\circ} \mathrm{C}$ for $5 \mathrm{~h}$ in air.

\subsection{Experimental conditions}

Powder X-ray diffraction measurements $(X R D)$ were recorded using a Bruker $X$-ray diffraction unit $\mathrm{Cu}$ Ka radiation $(\lambda=$ $1.5406 \AA$ ) at room temperature in $40 \mathrm{KV}$ and $30 \mathrm{~mA}$ at a scan speed of $1.2 \% \mathrm{~min}$.

The infrared absorption spectra of a KBr pressed pellet of the powdered sample was studied in the range $4000-400 \mathrm{~cm}^{-1}$ using a brucker alpha type spectrophotometer.

The Constant Rate Thermal Analysis (CRTA) experiments were carried out on an apparatus built in house and 100mg samples weighed in a silica-cell in the temperature range from $248 \mathrm{~K}$ up to $873 \mathrm{~K}$. Once the equilibrium temperature is reached, the pressure above the sample is lowered using vacuum pumping system from 1 bar to the desired value (5hPa in our case). The pressure is continuously followed using a Pirani gauge (PID control) placed in proximity of the sample. The pressure signal produced by the Pirani gauge is sent to the furnace-heating controller. The heating of the sample then takes place in such a way as to keep constant, at the preset value, the vapour pressure generated by the sample [25,26].

\section{RESULTS AND DISCUSSION}

\subsection{Characterization of the initial material}

The starting material gave XRD pattern (Fig.1) in general agreement with the result reported in the JCPDS data card (700361) of pure hydromagnesite $\mathrm{Mg}_{5}\left(\mathrm{CO}_{3}\right)_{4}(\mathrm{OH})_{2} .4 \mathrm{H}_{2} \mathrm{O}$.

The structure of hydromagnesite belongs to the monoclinic system with space group $\mathrm{P} 2{ }_{1} / \mathrm{c}$ [40] and lattice parameters a $=$ $10,11 \AA ; b=8,97 \AA ; c=8,39 \AA ; \beta=114.6^{\circ} ; Z=2$ [40]. Both independent magnesium atoms have octahedral coordinations with average $\mathrm{Mg}-\mathrm{O}$ distances of $2.10 \AA$ and $2.04 \AA$, respectively [40]. The structure is based on a three dimensional framework of $\mathrm{MgO}_{6}$ octahedra and triangular carbonate ions [40]. There are large cavities with dimensions of about $4.6 \times 4.6 \times 4.1 \AA$ in the structure [40].

Fig. 2 shows the characteristic IR spectrum of the prepared hydromagnesite. Table 2 presents the wavenumbers of the absorption bands and their attributions. These attributions are based on works given in Ref.[41-44].

The water of crystallization of $\mathrm{Mg}_{5}\left(\mathrm{CO}_{3}\right)_{4}(\mathrm{OH})_{2} \cdot 4 \mathrm{H}_{2} \mathrm{O}$ absorbs in the $3459-3666 \mathrm{~cm}^{-1}$ regions and $1662 \mathrm{~cm}^{-1}$ which presumably correspond to $\mathrm{O}-\mathrm{H}$ stretching and $\mathrm{O}-\mathrm{H}$ bending vibrations, respectively.

The most noteworthy features being the appearance of very strong absorption bands centered at 1431 and $1490 \mathrm{~cm}^{-1}$ which are assigned to the asymmetric stretching vibration of $\mathrm{CO}_{3}^{2-}$ whereas the band which absorbs at $1127 \mathrm{~cm}^{-1}$ is attributed to the symmetric stretching vibration mode of $\mathrm{CO}_{3}{ }^{2-}$. Absorption bands observed in the $801-887 \mathrm{~cm}^{-1} \mathrm{region} \mathrm{can}^{-}$ be assigned to the bending vibration of CO32- . The bands of doublet observed at $431 \mathrm{~cm}-1$ and $597 \mathrm{~cm}-1 \mathrm{can}$ be assigned to the stretching vibration of $\mathrm{MgO}$. 


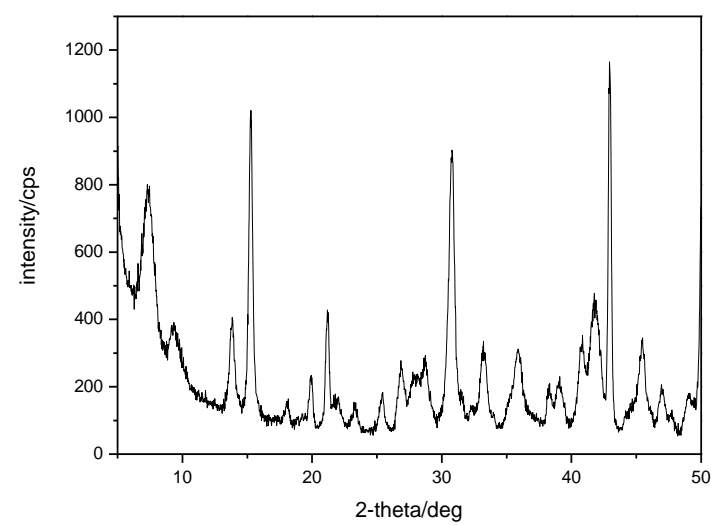

Fig.1. XRD pattern of the hydromagnesite prepared sample

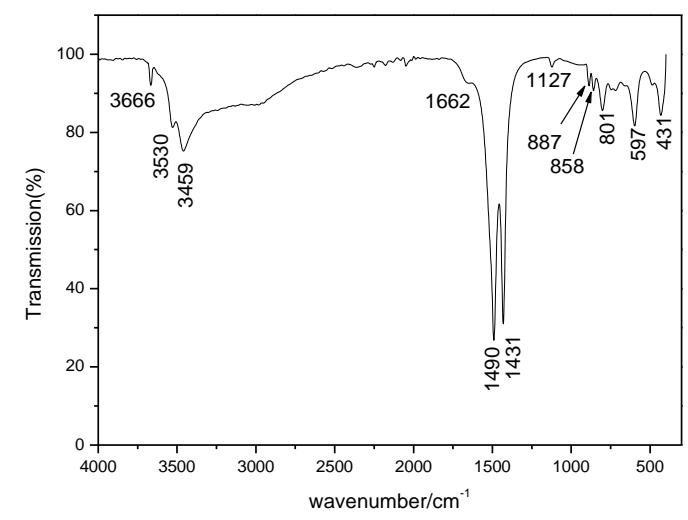

Fig.2. IR spectrum of the hydromagnesite prepared sample

Table 2. IR absorption wavenumbers of hydromagnesite and their assignments

\begin{tabular}{cc}
\hline Assignement & Absorption wavenumbers $/ \mathrm{cm}^{-1}$ \\
\hline $\mathrm{v}_{\text {as }}\left(\mathrm{CO}_{3}{ }^{2-}\right)$ & $1431-1490$ \\
$\delta\left(\mathrm{CO}_{3}{ }^{2-}\right)$ & $801-858-887$ \\
$\mathrm{v}_{\mathrm{s}}\left(\mathrm{CO}_{3}{ }^{2-}\right)$ & 1127 \\
$\mathrm{v}\left(\mathrm{OH}^{-}\right)$ & $3459-3530-3666$ \\
$\delta\left(\mathrm{H}_{2} \mathrm{O}\right)$ & 1662 \\
$\mathrm{v}(\mathrm{Mg}-\mathrm{O})$ & $431-597$ \\
\hline
\end{tabular}

\subsection{Thermal behavior}

The CRTA curves of hydromagnesite, shown in Fig. 3, were obtained by thermolysis of $100 \mathrm{mg}$ of sample under $5 \mathrm{hPa}$ partial pressure from 248 to $873 \mathrm{~K}$. The final mass loss at $873 \mathrm{~K}$ is $58 \%$ which corresponds to the theoretical loss $(56.89 \%)$ of five water molecules and four carbon dioxide molecules from the initial material.

The CRTA curves show the sample temperature (curve I) variation with time, controlled so as to keep constant the pressure (curve II) above the sample. In the case where the gas composition above the sample does not change, the vapour pressure is kept in a state of quasi-equilibrium: its rate of production during the dehydration is maintained constantly equal to its rate of elimination which is itself kept constant with time. Under these conditions, the length of each decomposition step varies proportionally with the mass loss. The plot of temperature vs. time thus obtained by CRTA is analogue to a thermogravimetric curve. Thus, the time is directly related to a given mass loss and a direct comparison between curves obtained via CRTA and conventional TG can be made.

Here, we have considered that, under $5 \mathrm{hPa}$, dehydration starts at $286 \mathrm{~K}$ which is the temperature at which the constant pressure regime, required for CRTA, is reached. At around $864 \mathrm{~K}$, a rapid drop in the pressure signal is observed indicating the end of the decomposition of the initial phase. The total thermolysis occurs within 77 hours.

In Fig. 4 is shown the sample temperature curve and its derivative. It is clear that the decomposition occurs in two main steps noted $(A-B)$ and $(C-D)$. However step $(A-B)$ is in the temperature range

$286-432 \mathrm{~K}$ and occurs within 34 hours whereas step (C-D) is in the temperature range $561-864 \mathrm{~K}$ and occurs within 43 hours. 


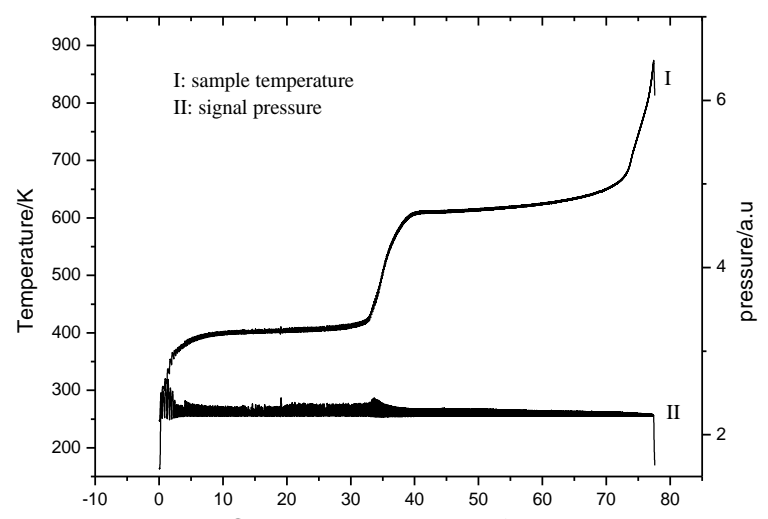

Fig.3. CRTAxpe@blwasime/of thermal decomposition of hydromagnesite at 5 hPa partial pressure

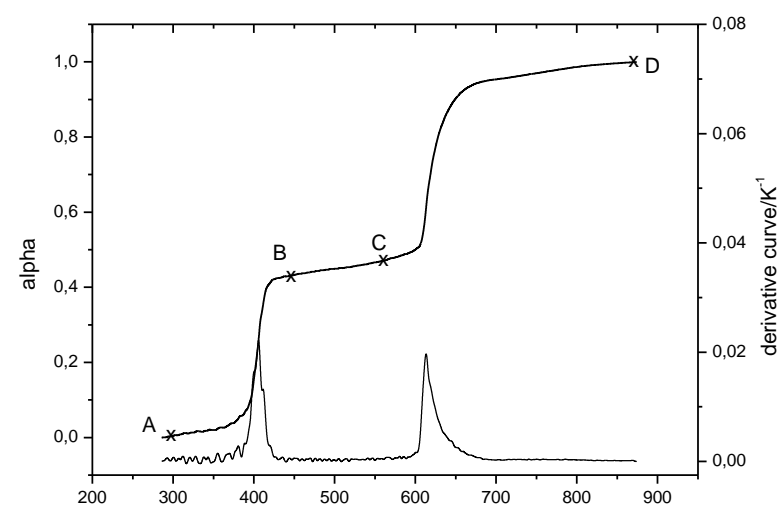

Fig.4. CRTA tefppperataterte curve of hydromagnesite thermal decomposition and its derivative

In Fig. 5 and 6 are shown, respectively, the X-ray diffractograms and IR spectra of hydromagnesite thermally decomposed at $473 \mathrm{~K}$ and at $873 \mathrm{~K}$ in CRTA conditions.

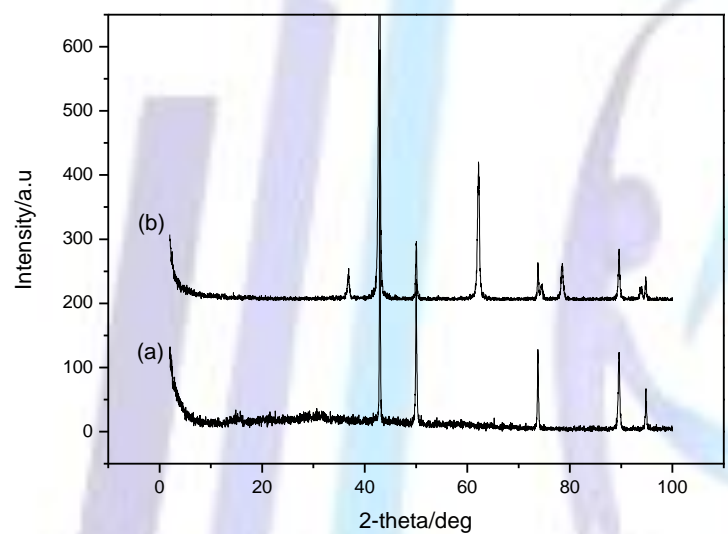

Fig.5. X -ray diffraction patterns of hydromagnesite decomposed at (a) $473 \mathrm{~K}$ and (b) $873 \mathrm{~K}$ in CRTA conditions

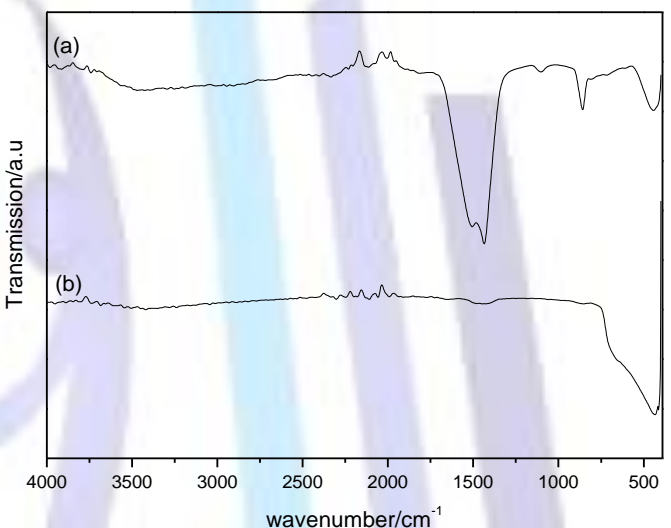

Fig.6. IR spectra of hydromagnesite decomposed at (a) $473 \mathrm{~K}$ and (b) $873 \mathrm{~K}$ in CRTA conditions

The analysis of the observed inter-reticular distances and absorption bands shows that:

- at $473 \mathrm{~K}$, the obtained phase is presumably $\mathrm{Mg}_{5}\left(\mathrm{CO}_{3}\right)_{4}(\mathrm{OH})_{2}$. Indeed, the observed diffraction peaks can't be attributed neither to $\mathrm{Mg}(\mathrm{OH})_{2}$ nor to $\mathrm{MgCO}_{3}$ or to $\mathrm{MgO}$ or to a mixture of these phases. This is confirmed by the disapperance of water absorption bands in 3459-3666 $\mathrm{cm}^{-1}$ and $1662 \mathrm{~cm}^{-1}$ regions and the persistance of $\mathrm{CO}_{3}{ }^{2-}$ absorption bands.

- at $873 \mathrm{~K}$, the observed diffraction peaks are attributed to a pure $\mathrm{MgO}$ phase (JCPDSN $\left.{ }^{\circ}: 89-4248\right)$ and the IR absorption bands of carbonate ion disappear.

and the formation of $\mathrm{Mg}_{5}\left(\mathrm{CO}_{3}\right)$ From these results, it is possible to conclude that the first step (A-B) corresponds to the release of four water molecules ${ }_{4}(\mathrm{OH})_{2}$. The second step corresponds to the dehydroxylation and the decarbonation of $\mathrm{Mg}_{5}\left(\mathrm{CO}_{3}\right)_{4}(\mathrm{OH})_{2}$. The decomposition scheme of hydromagnesite in CRTA conditions is :

Step (A-B) : [286K-432K]

$\mathrm{Mg}_{5}\left(\mathrm{CO}_{3}\right)_{4}(\mathrm{OH})_{2} \cdot 4 \mathrm{H}_{2} \mathrm{O}(\mathrm{sd}) \rightarrow \mathrm{Mg}_{5}\left(\mathrm{CO}_{3}\right)_{4}(\mathrm{OH})_{2}(\mathrm{sd})+4 \mathrm{H}_{2} \mathrm{O}(\mathrm{g})$

Step (C-D) : [561K-864K]

$\mathrm{Mg}_{5}\left(\mathrm{CO}_{3}\right)_{4}(\mathrm{OH})_{2}(\mathrm{sd}) \rightarrow 5 \mathrm{MgO}(\mathrm{sd})+\mathrm{H}_{2} \mathrm{O}(\mathrm{g})+4 \mathrm{CO}_{2}(\mathrm{~g})$

\subsection{Kinetic study}

\subsubsection{Theory}

In heterogeneous kinetics, in the simplest cases, the rate law is assumed to be expressed by the product of two terms: the change of degree of advancement of reaction $\alpha$ vs time can be described with the help of mathematical functions $f(\alpha)$ like those listed by sharp and al.[45] for a number of limiting cases. The second term depends only on temperature and pressure. If the Arrhenius law is obeyed, the rate law can be written: 


$$
\frac{d \alpha}{d t}=A a \times f(\alpha) \times \exp \left[\frac{-E a}{\mathbb{R} T}\right]
$$

Where $\mathrm{Aa}$ is the apparent pre-exponential factor and Ea is the apparent Arrhenius activation energy.

Since the above experiment is carried out in isokinetic conditions, we can state:

$\frac{d a}{d t}=$ constant $=C$

When using CRTA, a first idea of the kinetic law involved is easily obtained by comparing the experimental curves $\alpha$ vs $T$ with the set of isokinetic theoretical curves built by Criado et al.[46] and which easily split into three groups, on the basis of their general shape (Fig.7).

Process $\mathrm{F} 1$ corresponds to the case when the transformation rate of each single particle, is limited by a random nucleation, itself followed by a very rapid growth of the nuclei. Processes $\mathrm{R} 2$ and $\mathrm{R} 3 \mathrm{correspond}$ to an interfacial reaction. Processes D1, D2, D3, and D4 correspond to the case when the transformation rate is limited by diffusion through the layer of solid product and processes A2 and A3 correspond to nucleation and nuclei growth.

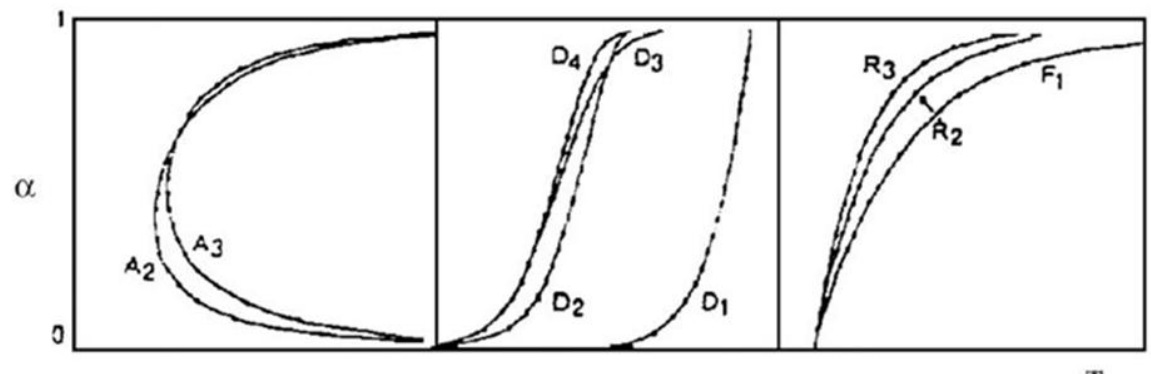

$\mathbf{T}$

Fig.7. Theoretical $\alpha$ vs T kinetic curves as obtained with the assumption of CRTA

\subsubsection{Experimental results}

The kinetic study of thermal decomposition of hydromagnesite consists of the calculation of the apparent activation energy and the determination of the most probable $f(\alpha)$ function for each decomposition step. From the above results, the first step $(A-B)$ is a dehydration reaction and the second step $(C-D)$ is a dehydroxylation and decarbonatation reactions.

Taking into account the theoretical weight loss after dehydroxylation (3.85\%) and decarbonatation (37.64\%) of the second step of hydromagnesite decomposition it is possible to consider that step (C-D) is essentially a decarbonation reaction.

$\alpha_{A D}, \alpha_{A B}$ and $\alpha_{C D}$ are respectively the degree of advancement of reaction associated to $(A-D),(A-B)$ and $(C-D)$ steps.

\subsubsection{Activation energy measurement}

The experimental activation energy Ea of a reaction can be obtained directly during a single rate jump experiment using a setup described elsewhere [47] where the reaction rate is changed between two values with periodical use of a second diaphragm (assessed by means of an automated vacuum valve) allowing to operate at two alternate pumping rates. Thus for a single value of $\alpha$ during a reaction, without any presumption of the reaction mechanism and whilst keeping all other parameters identical (sample mass, residual pressure) an expression of the activation energy, at a given value of $\alpha$, can be obtained:

$E a=\frac{R \times T_{1} \times T_{2}}{T_{2}-T_{1}} \ln \left[\frac{C_{2}}{C_{1}}\right]$

where $T_{1}$ and $T_{2}$ are the temperatures corresponding to the rates $\mathrm{C} 1$ and $\mathrm{C} 2$.

In our study, the activation energies were measured using two CRTA curves obtained under the same residual gas vapor pressure $(5 \mathrm{hPa})$ and at two different rates in the ratio $\mathrm{C}_{2}: \mathrm{C}_{1}=2$. Here again, temperatures can be evaluated for the same value of $\alpha$ and then an activation is energy deduced using equation (3).

In Fig. 8 are reported the different values of Ea as a function of the degree of advancement of reaction " $\alpha_{A D}$ ".

It is possible to observe two different variation of the activation energy corresponding to the steps (A-B) and (C-D) observed in Fig.4. Indeed, for a degree of reaction $\alpha_{A D}<0.40$, the activation energy has an average value equal to $60 \pm 5$ $\mathrm{kJ} . \mathrm{mol}^{-1}$. For $\alpha_{\mathrm{AD}}>0.4$, the average activation energy is equal to $95 \pm 6 \mathrm{~kJ}^{\mathrm{mol}}{ }^{-1}$. 


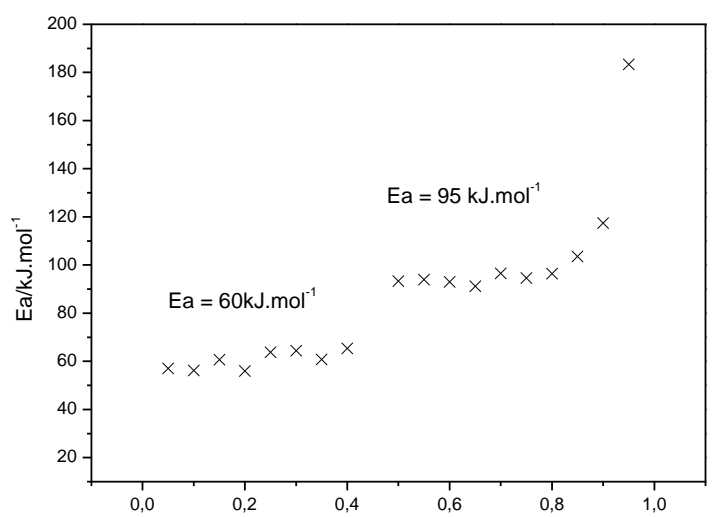

Fig. 8. Variation of experimentally apparent activation energy along the decomposition process at $5 \mathrm{hPa}$

\subsubsection{Estimation of the conversion function $f(\alpha)$}

An initial approach to the kinetic analysis of the reaction can be determined from a qualitative point of view by comparing the shape of the experimental curve with the theoretical isokinetic curves given in Fig .7.

A more elaborated method consists of following the change of $\ln [f(\alpha)]$ as a function of $1 / T$, which varies in a linear manner when the chosen function $f(\alpha)$ corresponds to the most probable single elementary process. The comparison of the activation energy determined from the slope of the line obtained via this latter method with the experimentally measured value adds a supplementary criterion to the elementary process.

Temperature curve for dehydration step (Fig.4) have symmetric sigmoidal shape and resembles those of diffusion mechanism (Dn). The temperature curve of decarbonatation (Fig.4) resembles those of F1, R2 and R3 mechanisms.

Since the apparent Arrhenius activation energies measured for each step are constant, it is possible to consider that each step occurs within a unique process characterized by the measured activation energy. So, plot of $\ln f(\alpha)$ vs $1 / T$ for each $f(\alpha)$ functions listed by Sharp can be carried out. In Tables 3 and 4 are given, the linear regression coefficient $r^{2}$, the apparent activation energy Ea and the apparent pre-exponential factor Aa for each kinetic law and for each step. For dehydration step, it can be seen that the kinetics laws of diffusion mechnaisms (D1, D2 and D4) gives the highest values of linear regression coefficient which allow us to assume them as the most probable elementary mechanisms for dehydration. The three dimensional diffusion mechanism D4 gives the closest activation energy $\left(58 \mathrm{~kJ}_{\mathrm{mol}}{ }^{-1}\right)$ to the one measured experimentally $\left(60 \mathrm{~kJ} \cdot \mathrm{mol}^{-1}\right)$.

Whereas for decarbonatation step F1, R2 and R3 kinetics laws gives the highest values of linear regression coefficient. The F1 kinetic law gives the closest activation energy $\left(90 \mathrm{~kJ}^{\mathrm{mol}}{ }^{-1}\right)$ to the one measured experimentally $\left(95 \mathrm{~kJ} . \mathrm{mol}^{-1}\right)$.

Based on the Ea value measured experimentally D4 and F1 laws seem to be the most probable kinetics laws for the dehydration step and decarbonation step, respectively.

Table 3. Linear regression coefficients $r$ and Arrhenius parameters for kinetic laws applied to the experimental CRTA curve $\left(0,03 \leq \alpha_{\mathrm{AB}} \leq 0,9 ; \mathrm{P}_{\mathrm{H} 2 \mathrm{O}}=5 \mathrm{hPa} ; \mathrm{C}=0.030 \mathrm{~h}^{-1}\right)$
Table 4. Linear regression coefficients $r$ and Arrhenius parameters for kinetic laws applied to the experimental CRTA curve $\left(0,03 \leq \alpha_{\mathrm{CD}} \leq 0,9 ; \mathrm{P}_{\mathrm{CO} 2}=5 \mathrm{hPa} ; \mathrm{C}=0.024 \mathrm{~h}^{-1}\right)$

\begin{tabular}{|c|c|c|c|}
\hline Kinetic law & $\mathrm{Ea} / \mathrm{kJ} \mathrm{mol}^{-1}$ & $\mathrm{~A} / \mathrm{s}^{-1}$ & $\mathrm{R}^{2}$ \\
\hline $\mathrm{A} 2$ & 16,4 & $6.12 .10^{-3}$ & 0,278 \\
\hline A3 & 7.6 & $3.74 .10^{-4}$ & 0.081 \\
\hline F1 & 42 & 47.22 & 0.652 \\
\hline R2 & 21 & $1.96 .10^{-2}$ & 0.652 \\
\hline R3 & 27 & 0.26 & 0.652 \\
\hline D1 & $\mathbf{3 7}$ & $\mathbf{0 . 8 4}$ & $\mathbf{0 . 9 4 4}$ \\
\hline D2 & $\mathbf{5 1}$ & $\mathbf{7 6 . 3 2}$ & $\mathbf{0 . 9 2 9}$ \\
\hline D3 & 73 & $6.10^{4}$ & 0.878 \\
\hline D4 & $\mathbf{5 8}$ & $\mathbf{2 3 6 . 2 6}$ & $\mathbf{0 . 9 1 0}$ \\
\hline
\end{tabular}

\begin{tabular}{|c|c|c|c|}
\hline Kinetic law & Ea/kJ.mol & $\mathrm{A} / \mathrm{s}^{-1}$ & $\mathrm{R}^{2}$ \\
\hline $\mathrm{A} 2$ & 41.14 & $9.6 .10-2$ & 0.675 \\
\hline $\mathrm{A} 3$ & 31.25 & $1.08 .10-2$ & 0.451 \\
\hline F1 & $\mathbf{8 8}$ & $\mathbf{1 0 8 9 . 6}$ & $\mathbf{0 . 9 8 2}$ \\
\hline R2 & $\mathbf{4 4}$ & $\mathbf{0 . 1 2 4}$ & $\mathbf{0 . 9 8 2}$ \\
\hline R3 & $\mathbf{6 0}$ & $\mathbf{2 . 5 4 3}$ & $\mathbf{0 . 9 8 2}$ \\
\hline D1 & 95 & 1.216 .103 & 0.682 \\
\hline D2 & 60 & 0.606 & 0.643 \\
\hline D3 & 137 & 1.632 .109 & 0.862 \\
\hline D4 & 145 & 4.340 .106 & 0.819 \\
\hline
\end{tabular}




\section{CONCLUSION}

This work, concerns the kinetic study of $\mathrm{Mg}_{5}\left(\mathrm{CO}_{3}\right)_{4}(\mathrm{OH})_{2} \cdot 4 \mathrm{H}_{2} \mathrm{O}$ thermal decomposition carried out by constant rate thermal analysis technique at $5 \mathrm{hPa}$ partial pressure. Under CRTA conditions, hydromagnesite decomposes in two steps:

- $\quad$ The first step occurs in $286 \mathrm{~K}-432 \mathrm{~K}$ temperature range and corresponds the dehydration (15.4\% wight loss) of hydromagnesite. The corresponding reaction is:

$$
\mathrm{Mg}_{5}\left(\mathrm{CO}_{3}\right)_{4}(\mathrm{OH})_{2} \cdot 4 \mathrm{H}_{2} \mathrm{O}(\mathrm{sd}) \quad \rightarrow \quad \mathrm{Mg}_{5}\left(\mathrm{CO}_{3}\right)_{4}(\mathrm{OH})_{2}(\mathrm{sd})+4 \mathrm{H}_{2} \mathrm{O}(\mathrm{g})
$$

The duration of this step is $32.76 \mathrm{~h}$, which corresponds to a reaction rate equal to $0.47 \mathrm{mg} \cdot \mathrm{h}^{-1}$.

The second step occurs in $561 \mathrm{~K}-864 \mathrm{~K}$ temperature range and corresponds to dehydroxylation $(3.85 \%$ weight loss) and decarbonatation (37.64\% weight loss) of the anhydrous hydromagnesite. The corresponding reaction is:

$\mathrm{Mg}_{5}\left(\mathrm{CO}_{3}\right)_{4}(\mathrm{OH})_{2}(\mathrm{sd}) \rightarrow 5 \mathrm{MgO}(\mathrm{sd})+\mathrm{H}_{2} \mathrm{O}(\mathrm{g})+4 \mathrm{CO}_{2}(\mathrm{~g})$

The duration of this step is $40.52 \mathrm{~h}$, which corresponds to a reaction rate equal to $0.93 \mathrm{mg} \cdot \mathrm{h}^{-1}$.

From kinetic point of view, the dehydration step occurs according to the three dimensional diffusion mechanism (D4) with apparent activation energy equal to $60 \mathrm{~kJ} \mathrm{~mol}^{-1}$ whereas the second step occurs according to random nucleation mechanism (F1) with apparent activation energy equal to $95 \mathrm{~kJ}^{\mathrm{mol}}{ }^{-1}$.

\section{REFERENCES}

[1] Fernandez A.I., Chimenos J.M., Segarra M., Fernandez M.A., Espiell F., Procedure toobtain hydromagnesite from a MgO-containing residue. Kinetic study. Ind. Eng. Chem. Res, 2000, 39, 3653-3658.

[2] Winchell A.N., Winchell H., 1951 Elements of Optical Mineralogy (Part II), John Wiley, New York.

[3] Palache C., Berman H., Frondel C., 1951 Dana's System of Mineralogy, 7th ed., John Wiley, New York.

[4] Kirk R.E., Othmer D.F., 1995 Encyclopedia of chemical technology, vol.15. New York: Wiley \& Sons.

[5] Haurie L., Fernandez A.I., Velasco J.I., Chimenos J.M., Lopez-Cuesta J.M., Espiell F., Effects of milling on the thermal stability of synthetic hydromagnesite, Mater. Res. Bull. 2007;42:1010-18

[6] Yan C., Xue D., Novel self-assembled MgO nanosheet and its precursors. J. Phys. Chem. B, 2005;109: 12358-61.

[7] Janet C.M., Viswanathan B., Viswanath R.P., Varadarajan T.K., Characterization and Photoluminescence Properties of MgO Microtubes Synthesized from Hydromagnesite Flowers. J. Phys. Chem. C, 2007; 111: 10267-72.

[8] Botha A, Strydom CA (2001) Preparation of a magnesium hydroxyl carbonate from magnesium hydroxide. Hydrometallurgy. 2001;62: 175-83.

[9] Sawada Y., Uematsu K., Mizutani N., Kato M., Thermal decomposition of hydromagnesite 4MgCO3· $\mathrm{Mg}(\mathrm{OH}) 2 \cdot 4 \mathrm{H} 2 \mathrm{O}$. J. Inorg. Nucl. Chem, 1978;40:979-82.

[10] Sawada Y, Uematsu K, Mizutani N, and Kato M. Thermal decomposition of hydromagnesite $4 \mathrm{MgCO} 3 \cdot \mathrm{Mg}(\mathrm{OH}) 2 \cdot 4 \mathrm{H} 2 \mathrm{O}$ under different partial pressures of carbon dioxide. Thermochim. Acta. 1978;27:4559.

[11] Sawada Y, Yamaguchi J, Sakurai O, Uematsu K, Mizutani N, and Kato M. Thermal decomposition of basic magnesium carbonates under high-pressure gas atmoshpheres. Thermochim. Acta. 1979;32:277-91.

[12] Sawada Y, Yamaguchi J, Sakurai O, Uematsu K, Mizutani N, and Kato M. Thermogravimetric study on the decomposition of hydromagnesite $4 \mathrm{MgCO} 3 \cdot \mathrm{Mg}(\mathrm{OH}) 2 \cdot 4 \mathrm{H} 2 \mathrm{O}$. Thermochim. Acta. 1979;33:127-40.

[13] Sawada Y, Yamaguchi J, Sakurai O, Uematsu K, Mizutani N, and Kato M. Isothermal differential scanning calorimetry on an exothermic phenomenon during thermal decomposition of hydromagnesite 4MgCO3. $\mathrm{Mg}(\mathrm{OH}) 2 \cdot 4 \mathrm{H} 2 \mathrm{O}$. Thermochim. Acta. 1979;34:233-37.

[14] Padeste C, Oswald HR, Reller A. The thermal behaviour of pure and nickel-doped hydromagnesite in different atmospheres. Mater. Res. Bull. 1991;26:1263-8.

[15] Choudhary V. R., Pataskar S. G., Gunjikar V. G., Zope G. B. Influence of preparation conditions of basic magnesium carbonate on its thermal analysis. Thermochim. Acta 1994;232:95-110.

[16] Rajeswara R.T., Chohan V.S. Kinetics of Thermal Decomposition of Hydromagnesite. Chem. Eng. Technol. 1995;18:359-63.

[17] Khan N., Dollimore D., Alexander K. and Wilburn F. W. The origin of the exothermic peak in the thermal decomposition of basic magnesium carbonate. Thermochim. Acta, 2001;367-368:321-33. 
[18] Koga N., Yamane Y., Effect of mechanical grinding on the reaction pathway and kinetics of the thermal decomposition of hydromagnesite. J. Therm. Anal. Cal. 2008;93:963-71.

[19] Vagvölgyi V., Frost R. L., Hales M., Locke A., Kristof J. and Horvath E. Controlled rate thermal analysis of hydromagnesite. J. Therm. Anal. Cal, 2008;92:893-7.

[20] Hollingbery L.A., Hull T.R. The thermal decomposition of huntite and hydromagnesite-A review. Thermochim. Acta, 2010;509:1-11.

[21] LIU Xin-wei, FENG Ya-li, LI Hao-ran, preparation of basic magnesium carbonate and its thermal decomposition kinetics in air. J. Cent. South Univ. Technol, 2011;18:1865-70.

[22] Hollingbery L.A., Hull T.R. The thermal decomposition of natural mixtures of huntite and hydromagnesite. Thermochim. Acta, 2012;528:45-52.

[23] Bhattacharjya D., Selvamani T., Mukhopadhyay I. Thermal decomposition of hydromagnesite, effect of morphology on the kinetic parameters. J. Therm. Anal. Cal, 2012;107:439-45.

[24] Ren H., Chen Z., Wu Y., Yang M., Chen J., Hu H., Liu J., Thermal characterization and kinetic analysis of nesquehonite, hydromagnesite, and brucite, using TG-DTG and DSC techniques. J. Therm. Anal. Cal, 2014;115:1949-60.

[25] Rouquerol J. Controlled transformation rate thermal analysis: the hidden face of thermal analysis. Thermochim. Acta 1989;144: 209-24

[26] Criado J.M. and Perez Maqueda L.A. in "Sample Controlled Thermal Analysis: Origin, Goals, Multiple Forms, Applications and Future", edited by Sorensen O. T. and Rouquerol J. (Kluwer Acad. Publishers, Dordrecht, 2003).

[27] Rouquerol J., A general introduction to SCTA and to Rate-controlled SCTA. J. Therm. Anal. Cal. 2003;72:1081-86.

[28] Criado J. M. Application of SCTA methods for kinetic analysis of solid state reactions and synthesis of materials. J. Therm. Anal. Cal, 2003;72:1097-8.

[29] Vagvoelgyi V., Daniel L. M., Pinto C., Kristof J., Frost R. L. and Horvath E. Dynamic and controlled rate thermal analysis of attapulgite. J. Therm. Anal. Cal. 2008;92:589-94.

[30] Vagvolgyi V., Hales M., Martens W., Kristof J., Horvath E. and Frost R. L. Dynamic and controlled rate thermal analysis of hydrozincite and smithsonite. J. Therm. Anal. Cal. 2008;92:911-16.

[31] Vagvolgyi V., Locke A., Hales M., Kristof J., Frost R. L., Horvath E. and Martens W. N. Mechanism for decomposition of aurichalcite-A controlled rate thermal analysis study. Thermochimi. Acta 2008;468:81-6.

[32] Vagvolgyi V., Sara J. P., Kristof J., Frost R. L. and Horvath E. Mechanism for hydrotalcite decomposition: A controlled rate thermal analysis study. J. Colloid Interface Sci. 2008;318:302-8.

[33] Waclawska I. Controlled rate thermal analysis of hyrated borates. J. Therm. Anal. Cal, 1998; 53:519-32.

[34] Nahdi K., Llewellyn P., Rouquerol F., Rouquerol J., Ariguib N.K., Ayedi M.T., Controlled Rate Thermal Analysis of kaolinite dehydroxylation: effect of water vapour pressure on the mechanism. Thermochim. Acta, 2002; 390:123-32.

[35] Nahdi K., Rouquerol F. and Ayadi M. T. Mg(OH)2 dehydroxylation: a kinetic study controlled by controlled rate thermal analysis (CRTA). Solid State Sci. 2009;11:1028-34.

[36] Nahdi K., Férid M. and Ayadi M. T. Thermal dehydration of $\mathrm{CeP} 3 \mathrm{O} 9 \cdot 3 \mathrm{H} 2 \mathrm{O}$ by controlled rate thermal analysis. J. Therm. Anal. Cal. 2009;96:455-61.

[37] Nahdi K., Férid M. and Ayadi M. T. Chemical preparation and thermal behavior of neodymium cyclotriphosphate pentahydrate NdP3O9.5H2O: A study by Controlled Rate Thermal Analysis (CRTA). Thermochim. Acta 2009;487:54-9.

[38] Kristóf J., Frost R.L., Martens W.N. and Horváth E. Separation of adsorbed and intercalated hydrazine in hydrazine-hydrate intercalated kaolinite by controlled rate thermal analysis. Langmuir 2002;18:1244-9.

[39] Kristof J., Frost R.L., Kloprogge J.T., Horvath E., Mako E., Detection of four different OH-groups in ground kaolinite with controlled-rate thermal analysis. J. Therm. Anal. Cal, 2002; 69:77-83.

[40] Akao M., Marumo F., Iwai S., The crystal structure of hydromagnesite. Acta Cryst. B 1974;30:2670-2.

[41] Sawada Y, Uematsu K, Mizutani N, and Kato M. Thermal decomposition of hydromagnesite $4 \mathrm{MgCO} 3 \cdot \mathrm{Mg}(\mathrm{OH}) 2 \cdot 4 \mathrm{H} 2 \mathrm{O}$ under different partial pressures of carbon dioxide. Thermochim. Acta. 1978;27:4559.

[42] Raade, G. Dypingite, a new hydrous basic carbonate of magnesium, from Norway. Am. Mineral. 
1970;55:1457-65.

[43] Janet C. M., Viswanathan B., Viswanath R. P., Varadarajan T. K. Characterization and Photoluminescence Properties of $\mathrm{MgO}$ Microtubes Synthesized from Hydromagnesite Flowers. J. Phys. Chem. Lett, 2007; 111:10267-72.

[44] White W. B., Infrared characterization of water and hydroxyl ion in the basic magnesium carbonate minerals. Am. Mineral, 1971; 56:46-53.

[45] Sharp J.H., Brindley G.W., Achar B.N.N. Numerical data for some commonly used solid state reaction equations. J. Am. Ceram. Soc, 1966;49:379-82.

[46] Criado J.M., Ortega A., Gotor F., correlation between the shape of controlled rate thermal analysis curves and the kinetics of solid state reactions. Thermochim. Acta, 1990;157:171-9.

[47] Ortega A., Akhouayri S., Rouquerol F., Rouquerol J., On the suitability of controlled transformation rate thermal analysis (CRTA) for kinetic studies: 1. Determination of the activation energy by rate-jump method. Thermochim. Acta, 1990;163:25-32. 